\title{
Giant Cell Tumor With Pathologic Fracture: Should We Curette or Resect?
}

\author{
Lizz van der Heijden MSc, P. D. Sander Dijkstra MD, PhD, \\ Domenico A. Campanacci MD, PhD, \\ C. L. Max H. Gibbons MD, PhD, Michiel A. J. van de Sande MD, PhD
}

Published online: 25 August 2012

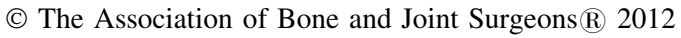

\begin{abstract}
Background Approximately one in five patients with giant cell tumor of bone presents with a pathologic fracture. However, recurrence rates after resection or curettage differ substantially in the literature and it is unclear when curettage is reasonable after fracture.

Questions/Purposes We therefore determined: (1) local recurrence rates after curettage with adjuvants or en bloc resection; (2) complication rates after both surgical techniques
\end{abstract}

Each author certifies that he or she, or a member of his or her immediate family, has no funding or commercial associations (eg, consultancies, stock ownership, equity interest, patent/licensing arrangements, etc) that might pose a conflict of interest in connection with the submitted article.

All ICMJE Conflict of Interest Forms for authors and Clinical Orthopaedics and Related Research editors and board members are on file with the publication and can be viewed on request.

Each author certifies that his or her institution approved or waived approval for the human protocol for this investigation and that all investigations were conducted in conformity with ethical principles of research.

This work was performed at the Leiden University Medical Center, Leiden, The Netherlands.

L. van der Heijden ( $)$, P. D. S. Dijkstra, M. A. J. van de Sande Department of Orthopaedic Surgery, Leiden

University Medical Center, Postzone J11-R70,

PO Box 9600, 2300 RC, Leiden, The Netherlands

e-mail: lizzvanderheijden@gmail.com;

L.van_der_Heijden@lumc.nl

D. A. Campanacci

Department of Oncologic and Reconstructive Orthopaedics,

Centro Traumatologico Ortopedico, Azienda Ospedaliero-

Universitaria Careggi, Florence, Italy

C. L. M. H. Gibbons

Oxford Sarcoma Service, Nuffield

Orthopaedic Centre, Oxford, UK and whether fracture healing occurred after curettage with adjuvants; and (3) function after both treatment modalities for giant cell tumor of bone with a pathologic fracture.

Methods We retrospectively reviewed 48 patients with fracture from among 422 patients treated between 1981 and 2009. The primary treatment was resection in 25 and curettage with adjuvants in 23 patients. Minimum followup was 27 months (mean, 101 months; range, 27-293 months).

Results Recurrence rate was higher after curettage with adjuvants when compared with resection (30\% versus $0 \%$ ). Recurrence risk appears higher with soft tissue extension. The complication rate was lower after curettage with adjuvants when compared with resection (4\% versus $16 \%)$ and included aseptic loosening of prosthesis, allograft failure, and pseudoarthrosis. Tumor and fracture characteristics did not increase complication risk. Fracture healing occurred in 24 of 25 patients. Mean Musculoskeletal Tumor Society score was higher after curettage with adjuvants (mean, 28; range, 23-30; $\mathrm{n}=18$ ) when compared with resection (mean, 25; range, 13-30; $\mathrm{n}=25$ ).

Conclusions Our observations suggest curettage with adjuvants is a reasonable option for giant cell tumor of bone with pathologic fractures. Resection should be considered with soft tissue extension, fracture through a local recurrence, or when structural integrity cannot be regained after reconstruction.

Level of Evidence Level III, therapeutic study. See Guidelines for Authors for a complete description of levels of evidence.

\section{Introduction}

Giant cell tumor of bone is a primary benign bone tumor with a peak incidence between the third and fifth decades and a slight predominance for females [28]. It is most 
commonly found in the epimetaphyseal region of the long bones [28]. Giant cell tumor of bone contains mononuclear histiocytic cells, multinucleated giant cells, and mononuclear stromal cells; the latter are believed to be neoplastic. Overexpression of receptor activator nuclear factor kappa-B ligand by mononuclear stromal cells promotes the recruitment of multinucleated giant cells [28]. Cathepsin $\mathrm{K}$, exclusively expressed by these giant cells, is believed to be the principal protease in giant cell tumor of bone [18]. This indicates the osteoclast-like giant cells are responsible for the osteolysis seen in giant cell tumor of bone. Pathologic fractures occur at first presentation in $9 \%$ to $30 \%$ of all patients with giant cell tumor of bone [4-6, $19,20,27]$ and are often intraarticular as a result of the epimetaphyseal location.

Curettage with adjuvants and en bloc resection are both considered treatment options for giant cell tumor of bone with a pathologic fracture. The use of curettage with adjuvants reportedly is associated with relatively high local recurrence rates $(12 \%-34 \%)[2,3,16]$. Most local recurrences occur within the first 2 postoperative years [15]. Although based on a relatively small series, O'Donnell et al. [20] suggested the presence of pathologic fractures would be associated with a higher recurrence risk after curettage through fracture contamination of surrounding soft tissues. However, more recent studies have suggested that this may not be the case $[2,3,16]$. The majority of giant cell tumors of bone with a pathologic fracture about the knee have reportedly been treated with resection and reconstruction with either allograft or tumor prosthesis [19]. Some authors consider resection and reconstruction the preferred treatment in patients with severe joint destruction or dislocated, comminuted, or intraarticular fractures [6]. Although the risk for local recurrence is generally low after en bloc resection $(0 \%-12 \%)[2,9,15,27]$, it is not necessarily the most favorable primary treatment. Considering the benign nature of the disease, the young patient population, the substantial complications, and the need for revision surgery, the aim for joint preservation is generally justified [12, 13, $19,22]$. The preferred surgical treatment for primary giant cell tumor of bone with a pathologic fracture therefore remains controversial [7, 9, 11, 20,21, 24].

Although presentation with a pathologic fracture is not uncommon for patients with giant cell tumor of bone, combining our collective experience is critical to the understanding of this difficult to study subject. In the present study, we therefore reviewed our multicenter experience of patients with giant cell tumor of bone presenting with a pathologic fracture to determine if tumor and fracture characteristics led to universally better or worse outcomes.

We therefore determined: (1) local recurrence rates after curettage with adjuvants or en bloc resection; (2) complication rates after both surgical techniques and whether fracture healing occurred after curettage with adjuvants; and (3) function after both treatment modalities for giant cell tumor of bone with a pathologic fracture.

\section{Patients and Methods}

We retrospectively evaluated 63 patients treated for giant cell tumor of bone with a pathologic fracture $(15 \%)$ from a total of 422 consecutive patients with giant cell tumor of bone treated in one of three tertiary referral centers specializing in the interdisciplinary treatment of bone and soft tissue tumors between 1981 and 2009. We excluded eight patients with less than 2-year followup, three patients who underwent primary treatment other than mentioned, two with axially located giant cell tumor of bone, and two with rapidly progressive (malignant) giant cell tumor with recurrent and metastatic disease eventually resulting in death at 4 and 9 months after initial surgery (Fig. 1). Both patients had eventually undergone resection (distal and proximal femur) for local recurrences and they developed pulmonary metastases $(3 \%)$. From the eight patients with less than 2-year followup (1-19 months; five resections, three curettage with adjuvants), none developed a local recurrence so far. These 15 exclusions left 48 patients with primary giant cell tumor of bone with a pathologic fracture for analysis in this tricenter retrospective study. Primary treatment consisted of en bloc resection $(n=25)$ or curettage with adjuvants $(\mathrm{n}=23)$. Local adjuvants were combinations of phenol, hydrogen peroxide, and polymethylmethacrylate (PMMA). There were 27 male and 21 female patients. Mean age was 36 years (range, 11-77 years). Most common locations of giant cell tumor of bone with a pathologic fracture were the distal femur $(n=23[48 \%])$, proximal humerus $(n=9$ [19\%]), and proximal tibia $(n=6[13 \%])$. Minimum followup of the living patients was 27 months (mean, 101 months; range, 27-293 months). One patient died from an unrelated disease. No patients were recalled specifically for this study; all data were obtained from medical records. The study was approved by the local ethics committee.

We collected data from medical records and included patient demographics, imaging, histopathological evaluation, tumor localization, soft tissue extension, fracture characteristics, fracture healing, date and type of surgical intervention, method of reconstruction, local recurrences, complications, functional outcome, and followup (Table 1). All data were complete. Conventional radiographs were available for all patients; preoperative MRI for 42 patients; and preoperative CT for the other six patients. Soft tissue extension was assessed on preoperative MRI. We considered soft tissue involvement as an entity only when this was a 


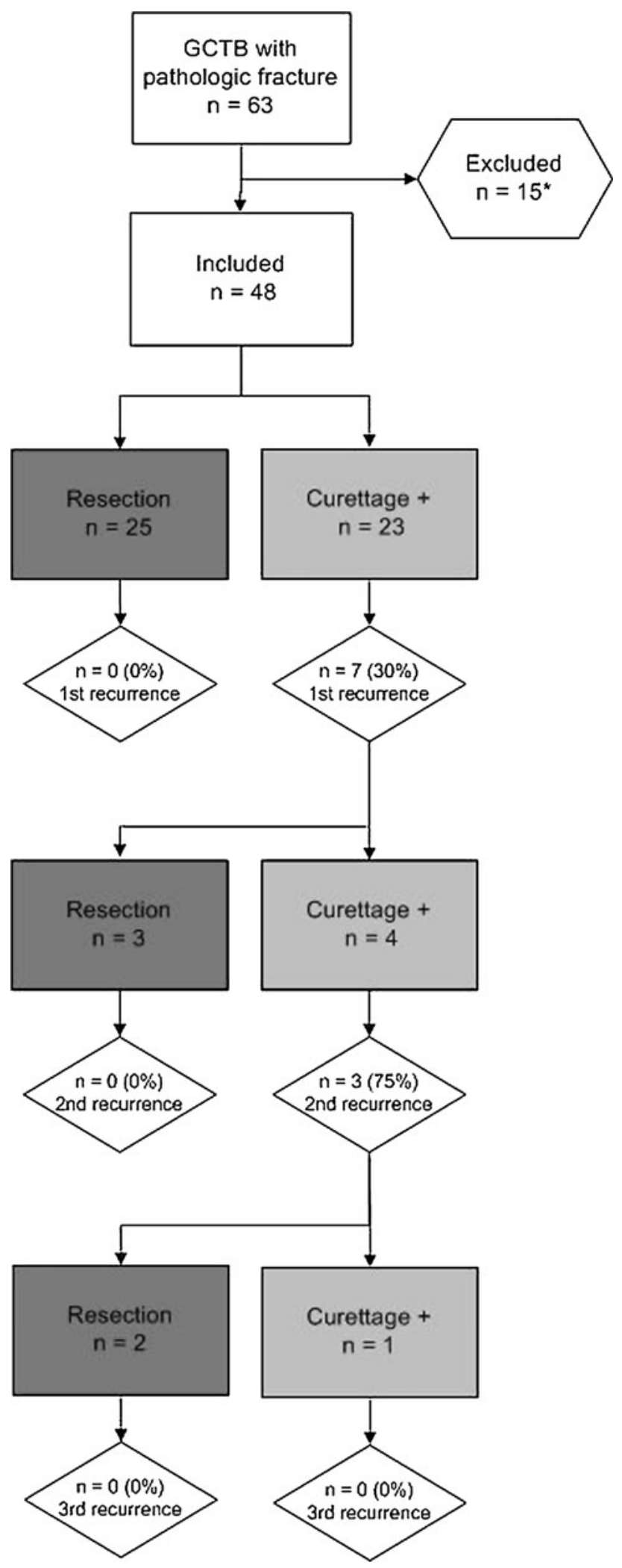

Fig. 1 Surgical treatment of a primary giant cell tumor of bone (GCTB) with a pathologic fracture and subsequent recurrences. * Patients with a followup of less than 2 years $(n=10)$, other primary treatment $(n=2)$, or axial location $(n=2)$ were excluded.
Table 1. Patient demographics

\begin{tabular}{|c|c|c|}
\hline Demographic & Mean & Range \\
\hline Age at diagnosis (years) & 39 & $11-77$ \\
\hline Time to recurrence (months) & 15 & $6-26$ \\
\hline \multirow[t]{3}{*}{ Followup (months) } & 101 & $27-293$ \\
\hline & \multicolumn{2}{|c|}{ GCTB with a pathologic fracture } \\
\hline & Number & Percent \\
\hline Total & 48 & \\
\hline \multicolumn{3}{|l|}{ Sex } \\
\hline Male & 27 & 56 \\
\hline Female & 21 & 44 \\
\hline \multicolumn{3}{|l|}{ Location } \\
\hline Proximal humerus & 9 & 19 \\
\hline Distal radius & 4 & 8 \\
\hline Distal ulna & 1 & 2 \\
\hline Proximal femur & 4 & 8 \\
\hline Distal femur & 23 & 48 \\
\hline Proximal tibia & 6 & 13 \\
\hline Distal tibia & 1 & 2 \\
\hline \multicolumn{3}{|l|}{ Tumor characteristics } \\
\hline Soft tissue extension & 18 & 38 \\
\hline Complex fractures & 13 & 27 \\
\hline Joint proximity $(<1 \mathrm{~cm})$ & 37 & 77 \\
\hline Intraarticular fractures & 16 & 33 \\
\hline \multicolumn{3}{|l|}{ Surgical treatment } \\
\hline En bloc resection & 25 & 52 \\
\hline Curettage with adjuvants & 23 & 48 \\
\hline PMMA & 21 & 91 \\
\hline Phenol & 20 & 87 \\
\hline Hydrogen peroxide & 3 & 13 \\
\hline
\end{tabular}

preexisting feature with cortex destruction and a tumor mass in the surrounding soft tissues; the fracture hematoma was not considered soft tissue extension.

The presumptive diagnosis was based on radiographic characteristics (ie, conventional radiographs and MRI) and clinical findings and history (eg, pain, swelling, preceding trauma); this was later confirmed by either preoperative (45) or intraoperative (six) biopsy. None of the patients underwent surgery without a proper histopathologic diagnosis.

All patients were surgically treated by one of six fellowshiptrained oncological orthopaedic surgeons (Center 1: PDSD, MAJS, AHMT; Center 2: DAC, RC; Center 3: CLMHG). Treatment of giant cell tumor of bone with a pathologic fracture differed (chi square: $p<0.001$ ) among the three centers. In one of three centers, curettage with adjuvants was preferred over resection in the presence of a pathologic fracture (Table 2). Complex fractures, intraarticular fractures, and subchondrally 
Table 2. Treatment for GCTB with a pathologic fracture per center

\begin{tabular}{llllllll}
\hline Treatment & Number & $\begin{array}{c}\text { Center 1 } \\
(\mathrm{n}=23)\end{array}$ & $\begin{array}{c}\text { Center 2 } \\
(\mathrm{n}=15)\end{array}$ & $\begin{array}{c}\text { Center 3 } \\
(\mathrm{n}=10)\end{array}$ \\
\hline $\begin{array}{c}\text { Curettage with } \\
\text { adjuvants }\end{array}$ & 23 & 18 & $78 \%$ & 1 & $7 \%$ & 4 & $40 \%$ \\
$\begin{array}{c}\text { En bloc resection } \\
\text { bloc }\end{array}$ & 25 & 5 & $22 \%$ & 14 & $93 \%$ & 6 & $60 \%$
\end{tabular}

$\mathrm{GCTB}=$ giant cell tumor of bone.

Table 3. Distribution of tumor and fracture characteristics among the three participating centers

\begin{tabular}{lrrrrrrr}
\hline Fracture characteristic & $\begin{array}{c}\text { Center 1 } \\
(\mathrm{n}=23)\end{array}$ & $\begin{array}{r}\text { Center 2 } \\
(\mathrm{n}=15)\end{array}$ & $\begin{array}{l}\text { Center 3 } \\
(\mathrm{n}=10)\end{array}$ & $\mathrm{p}$ value \\
\hline Soft tissue extension & 7 & $30 \%$ & 2 & $13 \%$ & 7 & $70 \%$ & 0.012 \\
Complex fractures & 3 & $13 \%$ & 6 & $40 \%$ & 4 & $40 \%$ & 0.088 \\
Intraarticular fractures & 8 & $35 \%$ & 7 & $47 \%$ & 3 & $30 \%$ & 0.719 \\
Joint proximity $(<1 \mathrm{~cm})$ & 16 & $69 \%$ & 14 & $93 \%$ & 7 & $70 \%$ & 0.216 \\
\hline
\end{tabular}

Table 4. Distribution of tumor and fracture characteristics between treatment modalities

\begin{tabular}{lllllll}
\hline Treatment modality & Number & $\begin{array}{l}\text { Curettage } \\
\text { with } \\
\text { adjuvants } \\
(\mathrm{n}=23)\end{array}$ & $\begin{array}{l}\text { En bloc } \\
\text { resection } \\
(\mathrm{n}=25)\end{array}$ & $\mathrm{p}$ value \\
\hline Soft tissue extension & 16 & 7 & $30 \%$ & 9 & $36 \%$ & 0.307 \\
$\begin{array}{l}\text { Complex fractures } \\
\begin{array}{l}\text { Intraarticular } \\
\text { fractures }\end{array}\end{array}$ & 13 & 4 & $17 \%$ & 9 & $36 \%$ & 0.123 \\
$\begin{array}{c}\text { Joint proximity } \\
\quad<1 \mathrm{~cm})\end{array}$ & 37 & 6 & $26 \%$ & 12 & $48 \%$ & 0.092 \\
\hline & 16 & $69 \%$ & 21 & $84 \%$ & 0.133 \\
\hline
\end{tabular}

located giant cell tumor of bone (less than $1 \mathrm{~cm}$ from the articular cartilage), which were assessed on imaging and operative reports, occurred equally in the three centers; only the incidence of soft tissue extension differed slightly (Table 3 ). Patient, tumor, and fracture characteristics were equal within both treatment groups (Table 4). Surgical management of the pathologic fracture consisted of two steps, namely surgical resection of the giant cell tumor of bone and fractured bone or joint reconstruction. Resection was performed within 1 week after the pathologic fracture occurred. In these cases, the tumor, fractured or involved bone, and contaminated soft tissue were resected and reconstructed (Table 1). In case of intraarticular fractures, the resection was performed transarticularly. En bloc resection was always followed by reconstruction with either allograft or cemented modular tumor prosthesis. Surgical margins were reviewed in operation and pathology reports. We performed intralesional treatment using curettage with adjuvants either before or after fracture healing. In 15 patients, immediate curettage with adjuvants and fracture reconstruction with use of PMMA only was performed. In only two patients internal fixation was necessary to maintain structural integrity after curettage. In two patients we awaited fracture consolidation using an external fixation and in six patients with use of a plaster cast before performing intralesional resection of the giant cell tumor of bone. In all patients who underwent curettage, we used local adjuvants to reduce the risk for local recurrence (Table 1). In two patients, cancellous bone graft was applied instead of PMMA because of considerable loss of cortical and subchondral bone stock. We used hydrogen peroxide in three patients as an alternative for phenol.

Postoperative treatment after curettage consisted of functional mobilization with partial weightbearing for at least 6 to 12 weeks. Weightbearing was increased when pain and radiographic followup indicated stable fusion of the fracture. Five patients needed additional immobilization using a (removable) cast for 6 to 12 weeks based on postoperative radiographs and clinical examination. In case of prosthetic reconstruction, immediate weightbearing was allowed; for the allograft reconstruction, this was dependent on union as assessed on radiographs.

The followup protocol consisted of radiography at 1.5 , 3 , and 6 months postoperatively followed by half yearly radiographs until 2 years postoperatively and yearly radiographs in the next years to detect local recurrences or complications. We performed MRI at 1, 2, 5, and 10 years postoperatively. We recorded local recurrences, complication rates, fracture healing, and function for both curettage with adjuvants and en bloc resection. Musculoskeletal Tumor Society (MSTS) scores were obtained to evaluate functional outcome and pain in the affected extremity [8]. We took the questionnaire at latest followup (mean, 101 months). MSTS scores were available for 43 patients. Five patients did not return the questionnaire and could not be contacted by telephone. A distinction between major complications requiring surgical intervention and minor complications demanding nonsurgical treatment was made. The primary oncological end point was a radiological or histological-proven local recurrence and, for the complication rate, failure of the prosthesis or allograft requiring surgical revision. Radiological signs for loosening of prostheses were not evaluated. We evaluated several variables potentially increasing the recurrence and complication risk: complex or intraarticular fractures, soft tissue extension, and subchondral giant cell tumor of bone.

Recurrence-free survival was assessed using KaplanMeier survival analysis and differences in survival between treatment groups were assessed using a log rank test. Local recurrence and complication rates were calculated. Univariate and multivariate (two variables) Cox regression analysis was performed to determine independent factors of influence on the recurrence and complication risk. Functional outcome (MSTS score) for both groups was compared with an unpaired t-test. We used SPSS 17.0 
(SPSS Inc, Chicago, IL, USA) to perform all statistical analysis.

\section{Results}

No recurrences occurred in the resection group, whereas in the curettage group, the recurrence-free survival rates were $74 \%$ and $70 \%$ at 2 and 5 years postoperative, respectively $(\mathrm{p}=0.003$ ) (Fig. 2). The local recurrence rate was $30 \%$ after curettage with adjuvants (seven of 23 ) and $0 \%$ after en bloc resection (zero of 25). Surgical margins were negative in 24 patients and marginal in one patient who underwent en bloc resection; no piecemeal resection was performed. All local recurrences were found at the site of the primary tumor and were confined to the bone in five patients and with an additional soft tissue component in two patients. No skip lesions or distant recurrences were reported. Because there were no recurrences in the resection cases, we only performed a risk analysis for local recurrence in the intralesional treatment group. The only factor increasing (hazard ratio $=4.8, \mathrm{p}=0.046$ ) recurrence risk after curettage with adjuvants in univariate analysis was preexisting tumor soft tissue extension (five recurrences in seven patients with soft tissue extension). Complex fractures $(\mathrm{p}=0.073)$, intraarticular fractures $(\mathrm{p}=0.76)$, or subchondral giant cell tumor of bone close to the articular cartilage $(p=0.94)$ did not increase the recurrence risk (Table 5). For simple fractures without soft tissue extension, the recurrence rate after curettage with adjuvants was only $7 \%$ (one of 14). All but one recurrence occurred within the first 2 years postoperatively; mean time to local recurrence was 15 months (range, 6-26 months; $\mathrm{n}=7$ ). Surgical treatment of all first and second local recurrences is summarized in a flowchart (Fig. 1).

The major complication rate was $4 \%$ after curettage with adjuvants (one of 23) and $16 \%$ after en bloc resection (four of $25)$. The one major complication in the intralesional treatment group was a pathologic fracture of the distal femur that did not heal after immediate curettage and cementation and developed a pseudarthrosis; this was successfully treated with cancellous bone graft and postoperative immobilization with a plaster cast. Minor complications after curettage with adjuvants (13\% [three of 23]) were chronic pain, superficial wound infection, and deep venous thrombosis; all were successfully treated nonsurgically. Fracture healing occurred in 22 of the 23 patients treated with curettage and adjuvants after a mean of 12 weeks (range, 6-48 weeks) either after immediate curettage with adjuvants $(n=14)$ or after treatment with external fixation $(n=2)$ or a plaster cast $(n=6)$ before surgery. Fracture healing was assessed by

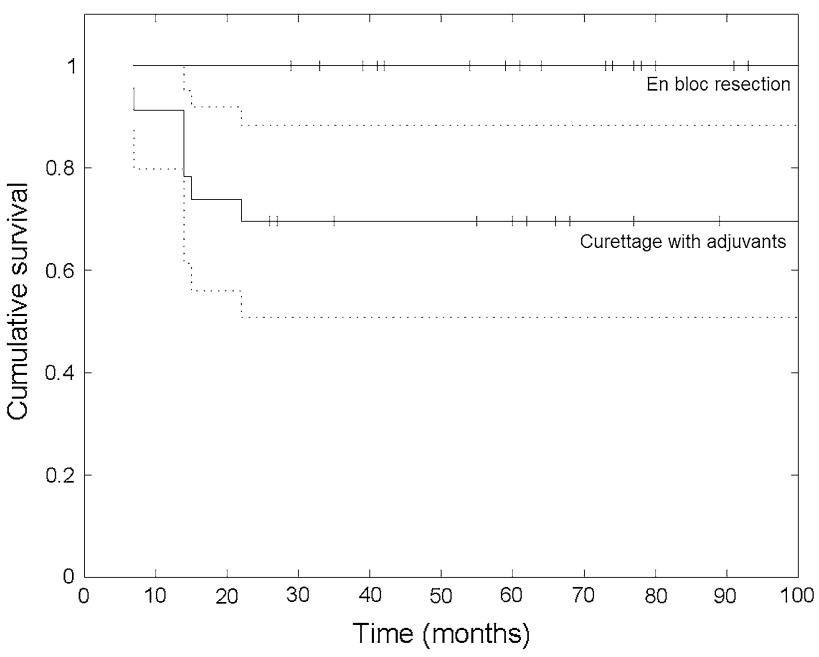

Fig. 2 Recurrence-free survival (RFS) after curettage with adjuvants (with 95\% confidence interval) and en bloc resection for giant cell tumor of bone with a pathologic fracture. After curettage with adjuvants, the RFS was lower $(\mathrm{p}=0.003)$ than after resection and was estimated at $74 \%$ and $70 \%$ at 2 and 5 years postoperatively, respectively. After resection, the RFS was $100 \%$.

Table 5. Factors of influence on recurrence and complication risk

\begin{tabular}{|c|c|c|c|c|c|}
\hline $\begin{array}{l}\text { Factors of } \\
\text { influence }\end{array}$ & Number & $\begin{array}{l}\text { Local } \\
\text { recurrence }\end{array}$ & $\begin{array}{l}\text { Hazard } \\
\text { ratio }\end{array}$ & $\begin{array}{l}95 \% \\
\text { confidence } \\
\text { interval }\end{array}$ & $\mathrm{p}$ value \\
\hline \multicolumn{6}{|c|}{$\begin{array}{l}\text { Influence on recurrence risk after curettage } \\
\text { with adjuvants }(\mathrm{n}=23)\end{array}$} \\
\hline \multicolumn{6}{|c|}{ Multivariate analysis } \\
\hline $\begin{array}{r}\text { Soft tissue } \\
\text { extension }\end{array}$ & 7 & 5 & 4.6 & $1.0-21$ & 0.053 \\
\hline $\begin{array}{l}\text { Complex } \\
\text { fracture }\end{array}$ & 4 & 3 & 3.8 & $0.83-17$ & 0.086 \\
\hline \multicolumn{6}{|c|}{ Univariate analysis } \\
\hline $\begin{array}{r}\text { Soft tissue } \\
\text { extension }\end{array}$ & 7 & 5 & 4.8 & $1.0-22$ & 0.046 \\
\hline $\begin{array}{c}\text { Complex } \\
\text { fracture }\end{array}$ & 4 & 3 & 4.0 & $0.88-18$ & 0.073 \\
\hline $\begin{array}{l}\text { Intraarticular } \\
\text { fracture }\end{array}$ & 6 & 2 & 1.2 & $0.07-34$ & 0.76 \\
\hline $\begin{array}{l}\text { Joint proximity } \\
(<1 \mathrm{~cm} \text { from } \\
\text { joint } \\
\text { cartilage })\end{array}$ & 16 & 5 & 1.1 & $0.15-7.6$ & 0.94 \\
\hline \multicolumn{6}{|c|}{$\begin{array}{l}\text { Influence on complication risk after } \\
\text { en bloc resection }(n=25)\end{array}$} \\
\hline \multicolumn{6}{|l|}{ Univariate analysis } \\
\hline Soft tissue & 9 & 0 & 1.8 & $0.25-13$ & 0.55 \\
\hline $\begin{array}{l}\text { Complex } \\
\text { fracture }\end{array}$ & 9 & 0 & 0.93 & $0.09-9.2$ & 0.95 \\
\hline $\begin{array}{l}\text { Intraarticular } \\
\text { fracture }\end{array}$ & 12 & 0 & 0.44 & $0.04-4.3$ & 0.48 \\
\hline Joint proximity & 21 & 0 & 0.27 & $0.04-1.9$ & 0.19 \\
\hline
\end{tabular}


conventional radiographs and clinical examination. After resection, major complications were reported in four patients. Two patients had aseptic loosening of tumor prostheses (two of 25 [8\%]); both were successfully revised. In one patient, the allograft humeral head fragmented; this was successfully replaced by a shoulder hemiprosthesis. One patient developed subluxation of the wrist after distal radius reconstruction with an autologous vascularized fibula inlay graft and osteosynthesis. Surgical correction was performed resulting in decreased ROM and persistent pain. Minor complications after resection (16\% [four of 25]) were reduced $\operatorname{ROM}(\mathrm{n}=3)$ and joint effusion $(\mathrm{n}=1)$. Decreased ROM improved after physiotherapy in one patient and was persistent in two. The complication risk was not increased by preexisting soft tissue extension $(\mathrm{p}=0.55)$, complex fractures $(\mathrm{p}=0.95)$, intraarticular fractures $(\mathrm{p}=0.48)$, or joint proximity $(\mathrm{p}=0.19)$ in univariate analysis (Table 5). We performed risk analysis for major complications only after resection.

Functional ability and pain as reported by patients at latest followup were superior $(\mathrm{p}=0.013)$ after curettage with adjuvants when compared with resection. Mean MSTS score after curettage was 28 (range, 23-30; $\mathrm{n}=18$ ). Fourteen patients had an MSTS score over 90\%, two $80 \%$ to $89 \%$, and two $60 \%$ to $79 \%$. Mean MSTS score after resection was 25 (range, 13-30; $\mathrm{n}=25$ ). Eleven patients had an outcome score greater than $90 \%$, seven between $80 \%$ and $89 \%$, five from $60 \%$ to $79 \%$, and two less than $60 \%$.

\section{Discussion}

Pathologic fracture is a relatively infrequent complication of giant cell tumor of bone, being a purely osteolytic primary skeletal lesion. It was commonly believed that pathologic fracture was associated with a higher recurrence risk as a result of the expected contamination of surrounding tissues [20]. En bloc resection reduces the recurrence risk dramatically and has therefore been preferred as the primary treatment [14]. However, more recent studies could not confirm pathologic fractures as a risk factor for local recurrence. Furthermore, articular resection may result in important morbidity and functional impairment. This created opportunities for further studies investigating the indication for and outcome of curettage with adjuvants for giant cell tumor of bone with a pathologic fracture [6, 7, 14]. Deheshi et al. [6] compared recurrence-free survival and functional outcome after curettage for both patients with and without pathologic fracture; outcomes were comparable. Dreinhöfer et al. [7] analyzed 10 of 15 patients with a pathologic fracture treated with curettage and PMMA and reported a recurrence rate of four of 10. Jeys et al. [14] evaluated treatment options for different types of fractures and concluded that curettage can be safe for cortical breach but that discrete fractures more often require resection. Thus, the appropriate treatment remains controversial. To address these controversies in the literature, we determined (1) local recurrence rates after curettage with adjuvants or en bloc resection; (2) complication rates after both surgical techniques and whether fracture healing occurred after curettage with adjuvants; and (3) functional outcome after both treatment modalities for giant cell tumor of bone with a pathologic fracture.

Our study has several limitations. First, patients were treated in three centers where indications for surgical treatment differed, possibly resulting in selection and treatment bias. This multicenter approach was needed to accrue sufficient numbers of cases of this relatively infrequent occurrence with its variable presentation. Indications for curettage were more extended in Center 1 than in the other centers; a majority of cases with soft tissue extension and/or intraarticular or complex fractures in this center were treated with curettage and adjuvants. It is therefore probable that the high overall recurrence rate after curettage is a result of selection bias based on different indications for curettage or resection. Second, long-term clinical outcomes of giant cell tumor of bone with pathologic fracture were not compared with outcomes of giant cell tumor of bone without pathologic fracture. We can draw conclusions from our results as to which surgical treatment option would be most favorable in the presence of a pathologic fracture, but a relative interpretation of results on local recurrences, complications, and functional outcome is possible only considering available literature. Third, patients received different local adjuvants after curettage; the creation of subgroups for local adjuvants could have addressed this inconsistency. However, because treatment groups were small, statistics would not be reliable. Furthermore, only two patients did not receive PMMA as cavity fill-up and hydrogen peroxide was used as an alternative for phenol in only three patients. We therefore compared an en bloc approach with an intralesional approach with due consideration of small differences regarding local adjuvant treatment.

In our study, the local recurrence rate for primary giant cell tumor of bone with a pathologic fracture was higher after curettage with adjuvants and lower after en bloc resection when compared with recent literature $[2-4,9,15$, 16]. However, we also treated difficult cases with curettage plus adjuvants; this probably resulted in the relatively high recurrence rate after curettage. If we consider only simple fractures without soft tissue extension, the recurrence rate was only $7 \%$, which is even lower than recurrence rates reported in the literature (Table 6). The pulmonary 


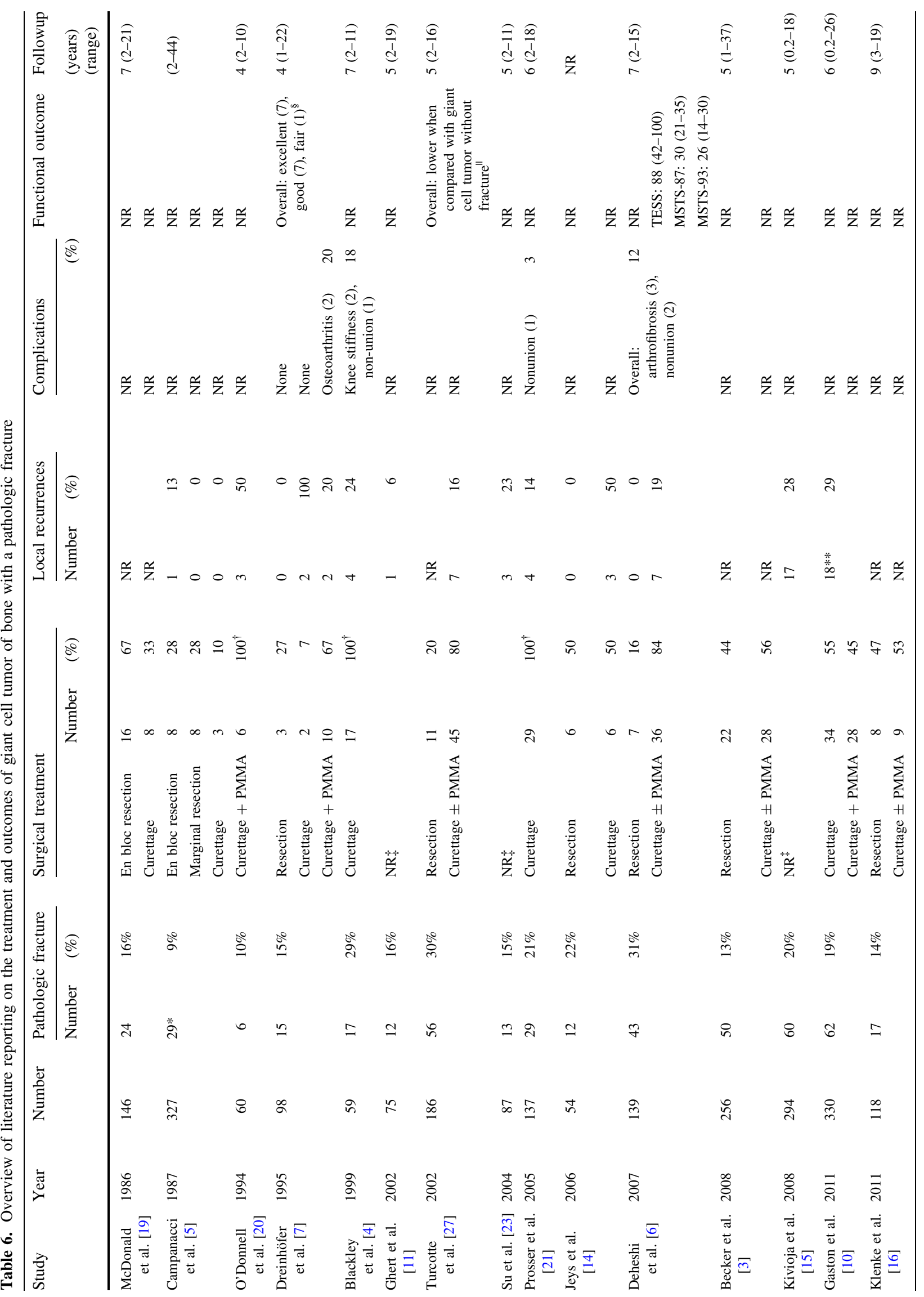




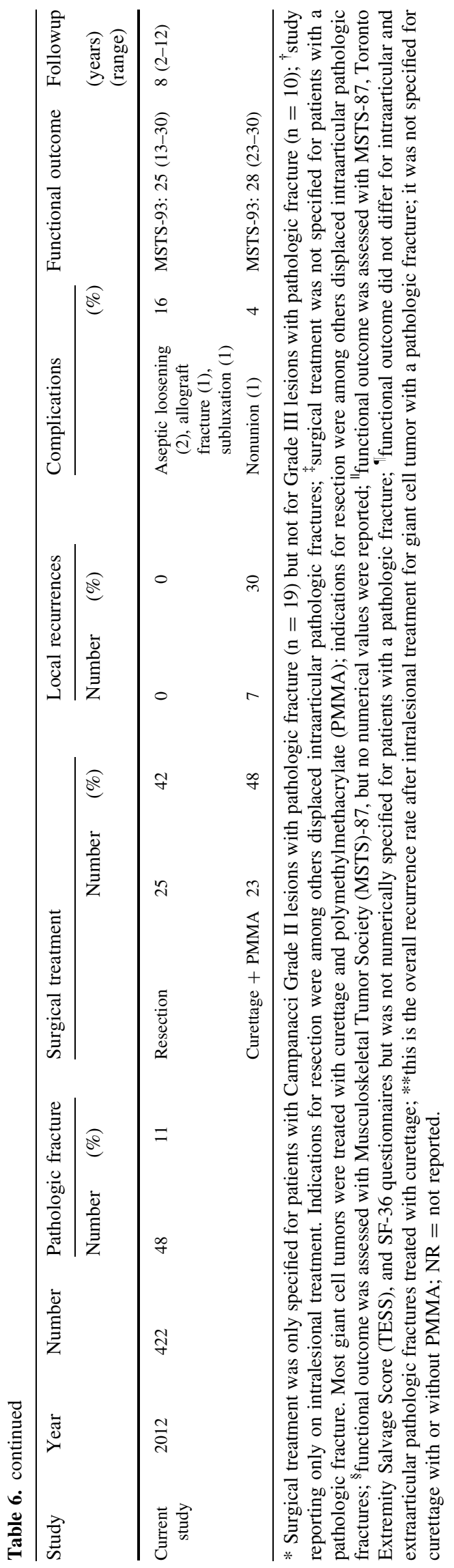

metastasis rate was comparable to that previously reported in the literature $(0 \%-4 \%)$ [16]. Therefore, we do not believe the relatively high recurrence rate affected the metastasis rate. Soft tissue extension is a known risk factor for local recurrence $[2,3,21]$; this was confirmed in our risk analysis. Regression analysis showed a higher recurrence risk only for patients with preexisting soft tissue extension (five of seven). Performing a thorough curettage is technically challenging in the presence of a pathologic fracture and soft tissue mass, because there is no adequate local adjuvant available that is applicable on soft tissues without inducing severe tissue necrosis. In principle, each dislocated fracture can also induce contamination of surrounding soft tissues. Complex fractures indeed had a high recurrence rate after curettage with adjuvants (three of four) and intralesional treatment was insufficient to obtain immediate local control. In these cases, en bloc resection can be considered to improve local control. In the near future, systemic targeted neoadjuvant therapy with receptor activator of nuclear factor kappa-B ligand inhibitor denosumab may facilitate wider indications for curettage in these cases. Such treatments result in calcification in giant cell tumor of bone and affected soft tissues, facilitating surgical removal through curettage and application of adequate adjuvants (eg, phenol, PMMA) [17, 25]. Intraarticular fractures did not demonstrate a higher recurrence rate after curettage with adjuvants (two of six). In the literature, intraarticular pathologic fractures were often resected as a result of technical difficulties in performing curettage and a presumed high risk for local recurrence [9, 16]. Likewise, in our series, 12 of 18 patients with an intraarticular fracture underwent primary resection. However, the recurrence risk was not influenced by the presence of an intraarticular fracture when treated with curettage plus adjuvants. Curettage can therefore be considered a feasible treatment option for intraarticular fractures. Subchondrally located giant cell tumor of bone had a similar acceptable recurrence rate after curettage with adjuvants (five of 16). Subchondral bone stock may be augmented by cancellous bone grafting before applying PMMA to prevent damage to the articular cartilage by the heat of the bone cement. Within our study population, this was performed only in case of an intraarticular fracture or complete loss of subchondral bone stock. A layer of approximately $1 \mathrm{~cm}$ is considered sufficient. Subsequent local recurrences were only reported in patients who underwent recurettage for a local recurrence, not for those who underwent resection (Fig. 1). This indicated local recurrences after giant cell tumor of tumor with a pathologic fracture can be successfully treated with en bloc resection.

The major complication rate was higher after resection when compared with curettage with adjuvants (16\% versus 
$4 \%)$. In the literature, complications were even more frequent after resection and reconstruction with allograft or tumor prosthesis when compared with our results (eg, allograft fracture $16 \%$, nonunion $19 \%$, aseptic loosening prosthesis $19 \%$, periprosthetic infection $11 \%-34 \%$ ) [1, 12, $13,16,19,22]$, but only few articles have reported on complications after surgical treatment for giant cell tumor of bone with a pathologic fracture in specific $[6,7,14]$. In one study, it has been postulated that the complication rate for giant cell tumor of bone with and without pathologic fractures is comparable [6]. As mentioned, we did not evaluate data on complications after treatment of giant cell tumor of bone without a pathologic fracture in this study. Multivariate regression analysis showed the complication risk after resection was independent of the complexity of fractures, soft tissue extension, intraarticular fractures, or joint proximity; the complication risk is thus inherent in the surgical treatment itself.

As expected, higher MSTS scores were reported after curettage with adjuvants (range, 23-30) when compared with resection (range, 13-30). Functional outcome after both treatment modalities was comparable to outcomes described in the literature $[7,8,26]$. However, wide variations in function after resection possibly make this finding less clinically relevant. Outliers with a poor function were patients with multiple surgical interventions for recurrences and/or complications; the number of surgical interventions should therefore be minimized.

The observations from our multicenter experience suggest a higher overall local recurrence rate after curettage with adjuvants for giant cell tumor of bone with a pathologic fracture when compared with resection. The local recurrence rate after curettage with adjuvants for simple fractures without soft tissue extension was not elevated. The risk for recurrence was only increased for coexistence of a pathologic fracture and soft tissue extension. Also, further recurrences only occurred after curettage with adjuvants. Fewer complications were reported after curettage when compared with resection. No tumor or fracture characteristics (including intraarticular fractures) influenced the risk for complications after surgery. Fracture healing was not impaired after curettage with adjuvants. Finally, functional outcome was better after curettage with adjuvants. Therefore, we believe that curettage can be considered in case of giant cell tumors with a relatively simple pathologic fracture. In more complicated fractures, the higher recurrence risk but better functional results and lower complication rates should be valued when performing intralesional treatment. En bloc resection should be considered in case of soft tissue extension, complex fractures, local recurrences, and when structural integrity cannot be regained after reconstruction.
Acknowledgments We thank Massimiliano Ippolito $\mathrm{MD}, \mathrm{PhD}$, orthopaedic surgeon, for his assistance in collecting data from patient records. We also thank Antonie $\mathrm{H}$. M. Taminiau $\mathrm{MD}, \mathrm{PhD}$, and Rodolfo Capanna MD, $\mathrm{PhD}$, who are both professors of orthopaedic oncology and surgically treated the majority of the patients.

\section{References}

1. Aponte-Tinao L, Farfalli GL, Ritacco LE, Ayerza MA, Muscolo DL. Intercalary femur allografts are an acceptable alternative after tumor resection. Clin Orthop Relat Res. 2012;470:728-734.

2. Balke M, Schremper L, Gebert C, Ahrens H, Streitbuerger A, Koehler G, Hardes J, Gosheger G. Giant cell tumor of bone: treatment and outcome of 214 cases. J Cancer Res Clin Oncol. 2008;134:969-978.

3. Becker WT, Dohle J, Bernd L, Braun A, Cserhati M, Enderle A, Hovy L, Matejovsky Z, Szendroi M, Trieb K, Tunn PU. Local recurrence of giant cell tumor of bone after intralesional treatment with and without adjuvant therapy. J Bone Joint Surg Am. 2008;90:1060-1067.

4. Blackley HR, Wunder JS, Davis AM, White LM, Kandel R, Bell RS. Treatment of giant-cell tumors of long bones with curettage and bone-grafting. J Bone Joint Surg Am. 1999;81:811-820.

5. Campanacci M, Baldini N, Boriani S, Sudanese A. Giant-cell tumor of bone. J Bone Joint Surg Am. 1987;69:106-114.

6. Deheshi BM, Jaffer SN, Griffin AM, Ferguson PC, Bell RS, Wunder JS. Joint salvage for pathologic fracture of giant cell tumor of the lower extremity. Clin Orthop Relat Res. 2007; 459:96-104.

7. Dreinhöfer KE, Rydholm A, Bauer HC, Kreicbergs A. Giant-cell tumours with fracture at diagnosis. Curettage and acrylic cementing in ten cases. J Bone Joint Surg Br. 1995;77:189-193.

8. Enneking WF, Dunham W, Gebhardt MC, Malawar M, Pritchard DJ. A system for the functional evaluation of reconstructive procedures after surgical treatment of tumors of the musculoskeletal system. Clin Orthop Relat Res. 1993;286:241-246.

9. Errani C, Ruggieri P, Asenzio MA, Toscano A, Colangeli S, Rimondi E, Rossi G, Longhi A, Mercuri M. Giant cell tumor of the extremity: a review of 349 cases from a single institution. Cancer Treat Rev. 2010;36:1-7.

10. Gaston CL, Bhumbra R, Watanuki M, Abudu AT, Carter SR, Jeys LM, Tillman RM, Grimer RJ. Does the addition of cement improve the rate of local recurrence after curettage of giant cell tumours in bone? J Bone Joint Surg Br. 2011;93:1665-1669.

11. Ghert MA, Rizzo M, Harrelson JM, Scully SP. Giant-cell tumor of the appendicular skeleton. Clin Orthop Relat Res. 2002;400: 201-210.

12. Henderson ER, Groundland JS, Pala E, Dennis JA, Wooten R, Cheong D, Windhager R, Kotz RI, Mercuri M, Funovics PT, Hornicek FJ, Temple HT, Ruggieri P, Letson GD. Failure mode classification for tumor endoprostheses: retrospective review of five institutions and a literature review. J Bone Joint Surg Am. 2011;93:418-429.

13. Jeys LM, Grimer RJ, Carter SR, Tillman RM. Periprosthetic infection in patients treated for an orthopaedic oncological condition. J Bone Joint Surg Am. 2005;87:842-849.

14. Jeys LM, Suneja R, Chami G, Grimer RJ, Carter SR, Tillman RM. Impending fractures in giant cell tumours of the distal femur: incidence and outcome. Int Orthop. 2006;30:135-138.

15. Kivioja AH, Blomqvist C, Hietaniemi K, Trovik C, Walloe A, Bauer HC, Jorgensen PH, Bergh P, Folleras G. Cement is recommended in intralesional surgery of giant cell tumors: a Scandinavian Sarcoma Group study of 294 patients followed for a median time of 5 years. Acta Orthop. 2008;79:86-93. 
16. Klenke FM, Wenger DE, Inwards CY, Rose PS, Sim FH. Giant cell tumor of bone: risk factors for recurrence. Clin Orthop Relat Res. 2011;469:591-599.

17. Kostenuik PJ, Nguyen HQ, McCabe J, Warmington KS, Kurahara C, Sun N, Chen C, Li L, Cattley RC, Van G, Scully S, Elliott R, Grisanti M, Morony S, Tan HL, Asuncion F, Li X, Ominsky MS, Stolina M, Dwyer D, Dougall WC, Hawkins N, Boyle WJ, Simonet WS, Sullivan JK. Denosumab, a fully human monoclonal antibody to RANKL, inhibits bone resorption and increases BMD in knockin mice that express chimeric (murine/human) RANKL. $J$ Bone Miner Res. 2009;24:182-195.

18. Lindeman JH, Hanemaaijer R, Mulder A, Dijkstra PDS, Szuhai $\mathrm{K}$, Bromme D, Verheijen JH, Hogendoorn PCW. Cathepsin K is the principal protease in giant cell tumor of bone. Am J Pathol. 2004;165:593-600.

19. McDonald DJ, Sim FH, McLeod RA, Dahlin DC. Giant-cell tumor of bone. J Bone Joint Surg Am. 1986;68:235-242.

20. O'Donnell RJ, Springfield DS, Motwani HK, Ready JE, Gebhardt MC, Mankin HJ. Recurrence of giant-cell tumors of the long bones after curettage and packing with cement. J Bone Joint Surg Am. 1994;76:1827-1833.

21. Prosser GH, Baloch KG, Tillman RM, Carter SR, Grimer RJ. Does curettage without adjuvant therapy provide low recurrence rates in giant-cell tumors of bone? Clin Orthop Relat Res. 2005;435:211-218.

22. Shehadeh A, Noveau J, Malawer M, Henshaw R. Late complications and survival of endoprosthetic reconstruction after resection of bone tumors. Clin Orthop Relat Res. 2010;468:28852895.

23. Su YP, Chen WM, Chen TH. Giant-cell tumors of bone: an analysis of 87 cases. Int Orthop. 2004;28:239-243.

24. Szendroi M. Giant-cell tumour of bone. J Bone Joint Surg Br. 2004;86:5-12.

25. Thomas D, Henshaw R, Skubitz K, Chawla S, Staddon A, Blay JY, Roudier M, Smith J, Ye Z, Sohn W, Dansey R, Jun S. Denosumab in patients with giant-cell tumour of bone: an open-label, phase 2 study. Lancet Oncol. 2010;11:275280.

26. Turcotte RE. Giant cell tumor of bone. Orthop Clin North Am. 2006;37:35-51.

27. Turcotte RE, Wunder JS, Isler MH, Bell RS, Schachar N, Masri BA, Moreau G, Davis AM. Giant cell tumor of long bone: a Canadian Sarcoma Group study. Clin Orthop Relat Res. 2002; 397:248-258.

28. Werner M. Giant cell tumour of bone: morphological, biological and histogenetical aspects. Int Orthop. 2006;30:484-489. 